\title{
Досвід використання довготривалої електростимуляції при ушкодженнях нервів, поєднаних з ішемією м'язів передпліччя
}

\begin{abstract}
Мета роботи: підвищити ефективність лікування хворих з ушкодженнями нервів, поєднаних з ішемією м’язів передпліччя шляхом використання методик реконструктивної хірургії та довготривалої електростимуляції нервів.

Матеріали і методи. Проведено аналіз хірургічного лікування десяти хворих з травмою нервів, поєднаних з супракондилярними переломи плечової кістки, ускладнених ішемією м’язів передпліччя. Представники чоловічої статі складали 80 \% обстежених, жіночої - 20 \%. Середній термін від моменту отримання травми до проведення реконструктивного втручання становив 4,7 місяців. В усіх випадках проведено хірургічне лікування - невроліз, аутопластика, зшивання нервів, ангіоліз, видалення дегенеративно змінених тканин в межах найбільшої щільності фасціально-кісткових проміжків. У 8 випадках реконструктивне нейрохірургічне втручання завершувалось імплантацією системи для довготривалої прямої електростимуляції нервів “Ней-Сі ЗМ” (ВЕЛ, Україна).

Результати досліджень та їх обговорення. Запропонована методика дозволила досягти суттєвого поліпшення результатів лікування у 80 \% постраждалих. Враховуючи складний механізм розвитку змін м’язового апарату внаслідок денерваційного та ішемічного генезу, усунення щонайменше денерваційних ефектів, шляхом стимуляції регенераційного потенціалу ушкодженого периферичного нерва є доволі перспективним напрямком.
\end{abstract}

Ключові слова: травма нервів; контрактура Фолькмана; реконструктивна хірургія; мікрохірургія; електростимуляція.

Постановка проблеми і аналіз останніх досліджень та публікацій. Травми периферійних нервів, за даними різних авторів, складають від 1,5 до 6 \% у структурі загального травматизму. Поєднані ушкодження - ушкодження декількох структур у межах одного сегмента верхньої кінцівки - виникають у 28 \% випадків усіх травм [1] та переважно супроводжується ушкодженнями прилеглих структур (сухожилки, м’язи, судини, кістки). Поєднання ушкоджень периферійних нервів 3 травмою магістральних судин верхньої кінцівки, що зустрічається у близько 23 \% випадків поєднаної травми [2, 3], значно погіршує перспективи відновлення функції. Сучасні досягнення хірургії судин, зокрема можливість отримати належну висококваліфіковану допомогу вже у найближчі терміни з моменту травми, в більшості випадків поєднаних ушкоджень дозволяють уникнути розвитку критичної ішемії тканин кінцівки. Несвоєчасне ж відновлення магістрального кровотоку призводить до незворотних ішемічних змін тканин. Окрім того, вважають, що будь-яка травма, котра супроводжується вираженим набряком тканин в обмежених фасцально-кісткових проміжках, гіпотетично може призвести до вторинних ішемічних ушкоджень усіх прилеглих структур [3-5]. Одним із основних етіологічних чинників розвитку вторинної критичної ішемії є супракондилярні переломи плечової кістки, переломи кісток передпліччя [5, 6]. Набряк тканин унаслідок переломів може призводити до збільшення внутрішньом'язового тиску до критичних для капілярного кровотоку значень - оклюзії капілярів. Фасціально-кісткові проміжки із найменшою здатністю до розтягнення (за що відповідає еластичність тканин, що їх формує) найбільше страждають від критичної ішемії із формуванням поширених ділянок ішемічного інсульту м’язового апарату [6-8]. Дегенеративні зміни м’язового апарату, що виникають унаслідок локальної судинної катастрофи, поступово зменшуються в периферійному напрямку, розвивається “еліпсоїдний інфаркт” за Seddon [9]. Критична ішемія м’язових структур із часом призводить до значного фіброзного переродження. Нервові структрури в зоні ішемічного ушкодження також зазнають змін, кінцевими проявами яких можуть бути повна анатомічна дезінтеграція та некротичний розпад на суттєвих відстанях від первинної зони ураження.

Клінічні прояви та зміни у м’язах передпліччя, що виникають в результаті ішемії тканин передпліччя, вперше описав Р. Фолькман у 1881 р., а клінічну характеристику тяжкості ураження при ішемічній контрактурі вперше дав Tsuge [10].

Різномантні стратегії відновлення функції кінцівки при вторинній ішемічній контрактурі запропоновані в літературі. Накладання іммоблізуючих шин, пасивне розтягання м’язів, корегуючі остеотомії, висічення фіброзних тканин, подовження та транспозиції сухожилків, вільна пересадка м’язів 
тощо здатні привести до відновлення функції з різним ступенем ефективності [2, 9, 11]. Систематизація обсягу наявного ушкодження $є$ головним чинником, котрий впливає на вибір належної лікувальної стратегії.

3 іншого боку, стратегії відновлення ефективної функції ушкоджених периферійних нервів у хворих із вторинною ішемічною контрактурою залишаються маловивченими. Лише в кількох вітчизняних та зарубіжних публікаціях констатується факт, що поєднана травма периферійних нервів значно погіршує перспективи відновлення функції кисті, оскільки умови для регенерації периферійних нервів у зоні ішемічного некрозу дуже несприятливі $[3,5,7]$. Відновлення функції травмованих периферійних нервів залишається складною й актуальною проблемою. Це завдання особливо ускладнюється у випадках, коли травма периферійних нервів призводить до вторинного ішемічного ушкодження не лише м’язів передпліччя, а й м'язів кисті.

Незважаючи на надскладні клінічні питання, котрі виникають при лікуванні вторинних ішемічних уражень верхньої кінцівки, основним фактором, що визначає добрий функціональний результат, є відновлення ефективної роботи кисті [12].

Матеріали та методи. Робота є ретроспективним описовим (обсерваційним) когортним одноцентровим дослідженням результатів лікування десяти хворих у відділенні відновлювальної нейрохірургії із рентгенопераційною ДУ “Інститут нейрохірургії імені акдеміка А. П. Ромоданова НАМН України” за період з 2012 по 2017 рік.

Критерї включення у дослідження: 1) супракондилярний переломом плечової кістки, що супроводжувався набряком кінцівки в ранньому періоді; 2) рентгенологічно підтверджена консолідація перелому; 3) вторинні ішемічні ушкодження одного та більше периферійних нервів верхньої кінцівки без електрофізіологічних ознак відновлення чутливої та рухової функції; 4) вторинні ішемічні зміни м’язового апарату передпліччя без клінічно та інструментально підтвердженої тенденції до розширення зони дегенеративних змін - формування стійкої картини контрактури Фолькмана; 5) відсутність хронічних інфекційних вогнищ у поверхневих та глибоких тканинах верхньої кінцівки.

Характеристика популяції хворих, включених у дослідження

У всіх десяти хворих (100 \%) ушкодження нервів кінцівки виникло внаслідок супракондилярного перелому плечової кістки, що супроводжувалося розвитком компартмент-синдрому із вираженою ішемією м’язів переднього (сім випадків
- 70 \%) та переднього і заднього (три випадки 30 \%) фасціальних футлярів м’язів передпліччя (ПФП; ЗФП) у ранньому періоді.

За даними доплерографії визначено магістральний тип кровотоку зі збереженням показників у межах нормативних значень пікової систолічної лінійної швидкості кровотоку (ЛШК) в плечовій артерії у семи пацієнтів в межах 65-68 см/с (при нормативній межі 50-100 см/с) із ішемією м'язів лише переднього фасціального футляра передпліччя. У трьох пацієнтів із ішемією м'язів переднього та заднього фасціальних футлярів передпліччя мали місце ознаки стенозування ділянки плечової артеpiї $з$ локальними змінами кровотоку за стенотичним типом (пікова систолічна ЛШК 175-200см/с) та ознаками колатерального кровотоку в артеріальних сегментах дистальніше зони ураження.

За даними ультразвукового дослідження (УЗД) м’язів, лише у трьох випадках ми мали чіткі ознаки незворотних змін у м'язах із значною поширеністю зони підвищеної ехощільності більше як 50 \% обсягу м’яза. В інших випадках дегенеративні зміни у м’язах можна було віднести до середньої важкості ураження (коефіцієнти гіпотрофії більше за 40 \% та ехощільності більше за 160 \% норми). Таким чином, вторинне ішемічне ушкодження м’язового апарату (MA) передньої поверхні передпліччя у семи хворих (із ушкодженням м'язів переднього фаціального футляра) відповідало II класу (середній ступінь) ушкодження за Tsuge. Ще у трьох хворих (із ушкодженням м'язів переднього і заднього фаціальних футлярів) - III класу ушкодження (тяжкий ступінь) ушкодження за Tsuge.

За віком хворі даної групи поділені на дві категорії: 6 дітей (60\%), середній вік яких становив 5,5 року (від 3 до 7 років), та 4 дорослих (40 \%), середній вік яких становив 41,7 року (від 24 до 54 років). Представники чоловічої статі складали 80 \% досліджуваних, жіночої - 20 \%. У жодного із хворих не виявлено клінічних та електрофізіологічних вторинних ушкоджень одного нерва. У семи випадках (70 \%) спостерігали вторинне ушкодження двох нервів кінцівки, а у трьох (30 \%) - трьох нервів верхньої кінцівки. У всіх десяти хворих вторинне ушкодження нервів верхньої кінцівки супроводжувалось травмою серединного (CH) та ліктьового (ЛН) нервів, у 3 із них у патологічний процес був залучений променевий нерв (ПрН) (30 \%). Середній час від моменту отримання травми до проведення реконструктивного втручання становив 4,7 місяця (від 1 до 14 місяців), причому п’яти хворим (50 \%) проведено реконструктивне втручання в строки до двох місяців після одержання травми, восьми хворим (80 \%) - в строки до п’яти місяців. 


\section{З ДОСВІДУ РОБОТИ}

Характеристика нейрохірургічних втручань, проведених хворим, включеним у дослідження

Видалення дегенеративно змінених тканин, ангіоліз плечової, променевої та ліктьової артерій завжди супроводжувався звільненням невральних структур у межах найбільшої щільності фасціально-кісткових проміжків. Невроліз нервів та ангіоліз супроводжувалися не лише фасціотоміями (особлива увага приділялась lacertus fibrosus) та тенотоміями (septum intermusculare mediale et laterale), а й переміщенням нервів (зокрема ЛН) у відносно інтактні тканини для запобігання можливості виникнення вторинної компресії після формування сполучнотканних рубців у ділянці хірургічного втручання.

Невроліз та ендоневроліз нервів верхньої кінцівки в межах н/3 плеча та в/3 передпліччя був виконаний у всіх десяти випадках. У двох випадках нейрохірургічне втручання передбачало виконання нейрорафії (один випадок) та аутологічної пластики (один випадок) одночасно із виконанням невролізу інших нервів верхньої кінцівки. У восьми випадках реконструктивне нейрохірургічне втручання завершувалось імплантацією системи для довготривалої прямої електростимуляції нервів “Ней-Сі ЗМ” (ВЕЛ, Україна) [16]. Для цього електроди системи підшивали до епіневрія нервів атравматичним шовним матеріалом Ethicon 6/0 на відстані не менше 0,5 см, а приймальну антену стимуляційної системи розташовували у невеликій підшкірній кишені на відстані 4-6 см від зони ушкодження. Сеанси електростимуляції нервів тривалістю до 15 хвилин проводиии тричі на день; розпочинали електростимуляцію на наступний день після операції.

Загальна характеристика клінічних та інструментальних методів оцінки вхідних (на момент включення) та вихідних показників вказаних рухових та чутливих функцій хворих, включенних у дослідження

Оцінювання вхідних даних та результатів реконструктивних нейрохірургічних втручань проводили в індивідуальному порядку для кожного 3 пацієнтів за допомогою:

1) клінічної неврологічної оцінки рухів та чутливості в ушкодженій кінцівці за допомогою MRC Scale (оцінка ступеня ураження/відновлення рухової сфери) та класифікації порушення/відновлення чутливості за Seddon;

2) ультразвукового дослідження артерій та м'язів верхньої кінцівки за допомогою ультразвукової діагностичної системи “Тoshiba Aplio MX”, Японія. Обстеження проведене за стандартною методикою [13, 14] за допомогою датчиків 5-10 Мгц лінійного типу; візуалізацію проводи- ли у режимах сірої шкали, кольорового допплерівського кодування, спектральної доплерографії. Під час обстеження оцінювали діаметри судин, їх прохідність, характер кровотоку (магістральний, колатеральний), вимірювали показники кровотоку (пікову систолічну та кінцеву діастолічну лінійну швидкість кровотоку в см/с. УЗД проводили у положенні пацієнта лежачи на спині. Досліджували дистальну ділянку підключичної артерії, пахвові, плечові, ліктьову, променеві артерії;

3) ультразвукового дослідження м'язів верхньої кінцівки, проведеного за стандартною методикою [14]. Для об’єктивізації даних виконували оцінку кількісних показників: товщини у спокої та при скороченні, ехощільності м’язів. Дослідження проводили на плечі - на межі середньої та нижньої третин, на передпліччі - на рівні верхньої третини. Оцінювали коефіцієнти: ступінь та коефіцієнт гіпотрофії; коефіцієнт ехощільності уражених м’язів, коефіцієнт скорочення, приймаючи за норму значення інтактних м’язів контралатеральної кінцівки $[8,15]$;

4) електронейроміографічного (ЕНМГ) дослідження, що проводилось на апараті “Нейро МВП” (Нейрософт, Іваново). За стандартними методиками виконували стимуляційну ЕМГ з дослідженням швидкості проведення збудження нервами та голкову ЕМГ. Голкову ЕМГ м’язів виконували послідовно в певних режимах реєстрації з використанням концентричних голкових електродів. Проводили дослідження активності введення електрода; дослідженняя спонтанної активності; визначення максимального довільного скорочення м'яза (дослідження показників інтерференційного паттерна) та визначення мінімального довільного напруження м’яза з вивченням параметрів потенціалів рухових одиниць [15, 17].

5) комплексного оцінювання відновлення ефективної функції кисті на основі здатності/нездатності відтворення чотирьох найрозповсюдженіших захватів під час щоденної активності [12]: а) кінцевого захвату (20 \% часу активності) - об’єкт утримується між нігтьовими фалангами першого та другого (третім) пальців кисті, б) ключового захвату (20 \% часу активності) - об’єкт утримується між нігтьовою фалангою першого пальця та радіарним краєм другого пальця, в) діагонального долонного захвату (15 \% часу активності) - об’єкт утримується між протиставленим першим пальцем чотирьом іншим, об’єкт розташований в площині, паралельній вісі кінцівки, г) поперечного долонного захвату (14 \% часу активності) - об’єкт утримується між протиставленим першим пальцем чотирьом іншим, об’єкт розташований в площині, паралельній вісі кінцівки (рис. 1). 


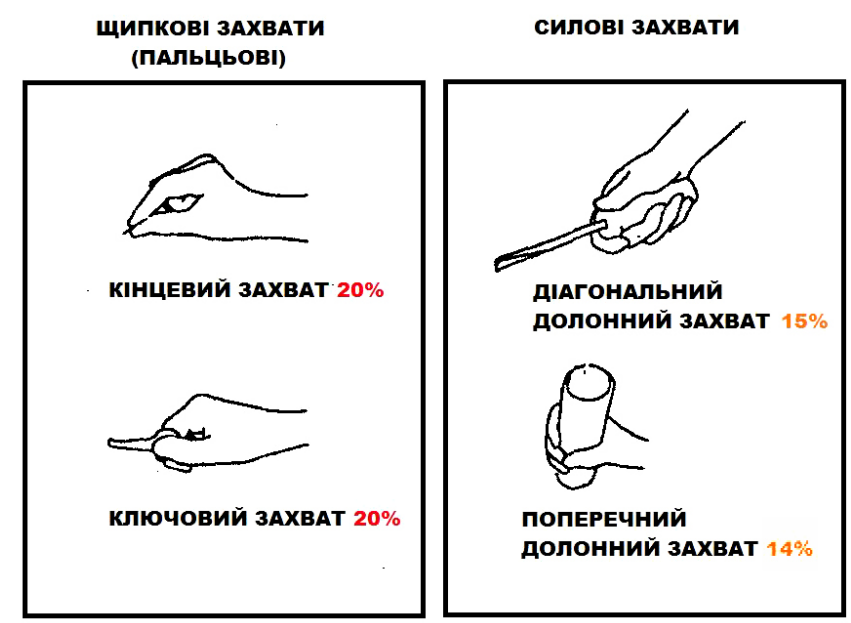

Рис. 1. Чотири основні захвати, що загалом задовольняють близько 70 \% вимог до функції кисті під час активної щоденної діяльності.

Для забезпечення будь-якого з чотирьох найбільш уживаних захватів необхідним є повноцінне функціонування м'язового апарату передпліччя та кисті, що забезпечується серединним, ліктьовим та променевим нервами.

Стабільність променево-зап'ясткового суглоба $€$ основною вимогою до функції м'язів переднього та заднього фаціальних футлярів. Для відтворення кінцевого захвату обов’язковою мінімальною умовою є наявність функції м'яза довгого згинача першого пальця, м'яза глибокого згинача другого (третього) пальців, м’язів підвищення першого пальця (іннервація за рахунок СН) та долонних міжп'ясних м'язів (іннервація за рахунок СН). Для відтворення ключового захвату обов'язковою мінімальною умовою $є$ наявність функції м'язів поверхневих та/чи глибоких згиначів другого пальця (іннервація за рахунок $\mathrm{CH}$ ) та привідних м'язів першого пальця (іннервація за рахунок ЛН). Для відтворення діагонального долонного захвату обов'язковою мінімальною умовою $є$ наявність функції м'язів поверхневих та/чи глибоких згиначів другого та третього пальців (іннервація за рахунок СН), довгого розгинача та довгого відвідного м’язів першого пальця (іннервація за рахунок ПрН) та привідних м’язів першого пальця (іннервація за рахунок ЛН). Для відтворення поперечного долонного захвату обов'язковою мінімальною умовою $€$ наявність функції м'язів поверхневих та/чи глибоких згиначів другого та третього пальців, м'яза довгого згинача першого пальця, м'язів підвищення першого пальця (іннервація за рахунок $\mathrm{CH}$ ).

6) власної оцінки функції кисті за допомогою Brief Michigan Hand Questionnaire - оцінювання результатів проведених хірургічних втручань проводили в передбачувані строки регенерації та при наступних зверненнях хворого (“на вимогу”) до моменту відсутності суттєвого прогресу у відновленні втрачених неврологічних функцій. При власному оцінюванні результатів кожним пацієнтом функції верхньої кінцівки за незадовільний результат приймали значення балів до 60 , задовільний - до 70 та добрий - вище 70 балів.

Результати досліджень та їх обговорення. Ефективне відновлення функції м'язового апарату (MRC 4 та вище) переднього фаціального футляра передпліччя - довгого згинача першого пальця, поверхневих та глибоких згиначів 2-5 пальців, згиначів кисті - в прогнозовані строки регенерації відбулось лише у п'яти хворих $(71,4$ \%) із вторинним ушкодженням двох нервів кінцівки (серединного та ліктьового). У шести пацієнтів (85,7 \%) із вторинним ушкодженням двох нервів кінцівки спостерігали ефективне відновлення як м'язів підвищення першого пальця, так і “внутрішніх” м'язів кисті, іннервація яких забезпечується ліктьовим нервом (MRC 4 та вище). У цих пацієнтів відновлення чутливості в автономній зоні іннервації серединного та ліктьового нервів відбулось у прогнозовані строки регенерації із усередненим показником S4 - ефективне відновлення дискримінаційної чутливості, що не відрізнялась від такої на інтактній кінцівці.

Помірно ефективне відновлення функції м'язового апарату (не нижче MRC 3) переднього фаціального футляра передпліччя - довгого згинача першого пальця, поверхневих та глибоких згиначів 2-5 пальців, згиначів кисті - відбулось у прогнозовані строки регенерації у всіх трьох хворих (100 \%) із вторинним ушкодженням трьох нервів кінцівки (серединного, ліктьового та променевого нервів). Помріно ефективне відновлення функції м'язового апарату (не нижче MRC 3) заднього фаціального футляра передпліччя - довгого розгинача першого пальця, загальних розгиначів 2-5 пальців, променевих розгиначів кисті відбулось у прогнозовані строки регенерації лише у одного хворого (33 \%) із вторинним ушкодженням трьох нервів кінцівки (серединного, ліктьового та променевого нервів). У жодного пацієнта із вторинним ушкодженням трьох нервів кінцівки не спостерігали ефективного відновлення м'язів підвищення першого пальця і “внутрішніх” м'язів кисті, іннервація яких забезпечується ліктьовим нервом (MRC 2 та нижче). Лише у одного пацієнта із вторинним ушкодженням трьох нервів спостерігали ефективне відновлення дискримінаційної чутливості в автономній зоні іннервації серединного та ліктьового нервів із показником S4, в 


\section{З ДОСВІДУ РОБОТИ}

інших двох випадках відновлена чутливість із показниками не вище S2 мала “захисний” характер.

У семи пацієнтів із вторинним ушкодженням серединного та ліктьового нервів відновлення МА ПФП, МА кисті та чутливості дозволило відновити кінцевий захват у 71 \% випадків, ключовий захват, діагональний долонний захват та поперечний долонний захват у 86 \% випадків. У трьох пацієнтів із вторинним ушкодженням серединного, ліктьового та променевого нервів відновлення МА ПФП та ЗФП, МА кисті та чутливості дозволило відновити кінцевий захват, ключовий захват, діагональний долонний захват та поперечний долонний захват у 33 \% випадків.

Загалом троє пацієнтів (30 \%) оцінили функцію верхньої кінцівки за BMHQ після проведених реконструктивних нейрохірургічних втручань як незадовільну - середній бал склав 44,4 (від 33,3 до 56,25). Один пацієнт (10 \%) оцінив функцію верхньої кінцівки після проведених реконструктивних нейрохірургічних втручань як задовільну - 60,4 бали. Шість пацієнтів (60 \%) оцінили функцію верхньої кінцівки після проведених реконструктивних нейрохірургічних втручань як добру - 87,5 бали.

Серед семи пацієнтів із вторинним ушкодженням двох нервів верхньої кінцівки один пацієнт (14,3 \%) оцінював відновлені функції верхньої кінцівки як незадовільні (56,3 балів), ще один (14,3 \%) хворий оцінив відновлені функції як задовільні (60,4 бали), решта п’ять пацієнтів (71,4%) оцінили відновлені функції як добрі (середній бал 87,5). Серед трьох пацієнтів із ушкодженням трьох нервів верхньої кінцівки, двоє (66,7 \%) оцінювали відновленні функції верхньої кінцівки як незадовільні (середній бал 38,5).

В усіх пацієнтів, котрі були незадоволені відновленими функціями верхньої кінцівки, у 100 \% випадків спостерігали вторинні ушкодження нервів та МА домінантної (правої) верхньої кінцівки. Серед пацієнтів, котрі оцінили відновлені функції верхньої кінцівки як добрі, переважали (5:1) вторинні ушкодження нервів та МА недомінантної (лівої) кінцівки.

Умови регенерації ушкоджень периферійних нервів, поєднаних з травмою магістральних судин, загалом, гірші, ніж при ізольованих ушкодженнях нервів.

Основною причиною незадовільних функціональних результатів $є$ не лише подовження термінів, в які виконується реконструктивне втручання, що призводить до розвитку фіброзно-жирового переродження м’язових волокон внаслідок тривалої денервації, а й формування вторинних ішемічних, часто незворотних, змін у м’язовому апараті на тлі судинних порушень.
Денерваційні процеси в м'язах при ізольованих ушкодженнях нервів травматичного ґенезу призводять до суттєвих сонографічних та електроміографічних змін структурно-функціонального стану [8]. Показники спонтанної активності при ЕМГ, зміна коефіцієнта гіпотрофії та ехощільності при УЗД є достатньо об’єктивними показниками, які характеризують структурно-функціональний стан повністю денервованого м’яза. Розвиток вторинної ішемії, що виникає внаслідок спонтанного припинення магістрального артеріального кровообігу, здатний значно поглибити структурнофункціональні зміни шляхом сумації патологічного впливу денервації та власне ішемії м’язової тканини компресійного та судинного ґенезу.

Численні терапевтичні та хірургічні методи відновлення функції нервів верхньої кінцівки, залучених у патологічний процес внаслідок прямої дії травмуючого чинника (перелом трубчастої кістки), вторинного впливу, зумовленного припиненням магістрального кровотоку та розвитком синдрому тривалого внутрішнього стиснення на великому протязі, здатні призвести в тій чи іншій мірі до позитивного функціонального результату.

Основною задачею нейрохірургічного лікування наслідків поєднаного ушкодження магістральних судин (за умов компенсованого кровотоку) та периферійних нервів (при збереженій їх анатомічній цілісності) $є$ усунення елементів зовнішньої та внутрішньої компресії задля створення максимально сприятливих умов для відновлення інтраневрального кровотоку - невроліз та ендоневроліз нервів.

Навіть за умови успішної декомпресії нервових структур, переважна більшість постраждалих потребують тривалого медикаментозного та фізіотерапевтичного лікування, зокрема, впливу електричними та магнітними полями на ушкоджені структури нервової системи. Довготривала електрична стимуляція довела свій позитивний вплив на регенерацію ушкодженого периферійного нерва в численних експериментальних працях. Існує лише невелика кількість суто клінічних досліджень, які підтверджують можливість суттєво покращити функціональні результати відновлення при поєднанні хірургічної декомпресії нерва та його тривалої електричної стимуляції. Враховуючи складний механізм розвитку змін м'язового апарату денерваційного та ішемічного генезу, усунення, щонайменше, денерваційних ефектів, шляхом стимуляції регенераційного потенціалу ушкодженого периферійного нерва, є доволі перспективним напрямком.

В представленому дослідженні у 80 \% випадків внутрішня та зовнішня декомпресія ушкоджених нервових структур поєднувалась із імплантацією системи для тривалої електростимуляції. 
Проаналізувавши результати проведених хірургічних втручань у пацієнтів із поєднанним ушкодженням нервів та судин верхньої кінцівки можна стверджувати, що на якісний (функціональний) аспект відновлення МА ПФП, ЗФП, МА кисті та чутливості в автономній зоні іннервації ушкоджених нервів найбільше впливали строки після травми та вік хворих. У пацієнтів із середнім терміном від травми до проведення реконструктивного втручання до п'яти місяців у віці до семи років (діти) проведені реконструктивні втручання дозволили повністю відновити функцію ушкодженої кінцівки.

На нашу думку, розвиток доопераційної неврологічної симптоматики на грунті ушкодження кісткового апарату плеча в першу чергу був пов'язаний із незавершеним розвитком компенсаторних можливостей колатерального кровообігу в ділянці плеча - ліктьової ямки - передпліччя. Терміни, в які виконувалось реконструктивне втручання, не були критичними для розвитку незворотних змін МА на грунті критичної для нервових структур ішемії, відповідно, відновлення інтраневрального коровообігу, кровообігу магістральними судинами верхньої кінцівки в терміни, що не перевищували критичні, дозволило відновити функцію як МА ПФП-ЗФП, так і МА кисті, чутливості в більш дистально розташованих відділах ушкодженої верхньої кінцівки.
У дорослих пацієнтів із термінами від травми до проведення реконструктивного втручання, що перевищували критичні (більше п'яти місяців), переродження м'язового апарату передпліччя, кисті та в певній мірі незворотні зміни в нервових стовбурах, які відбулися на грунті тривалої персистентної ішемії, не дозволили досягти належних функціональних результатів. Слід зазначити, що навіть за відсутності суттєвого регресу рухового неврологічного дефіциту (враховуючи характер змін МА), проведені реконструктивні втручання дозволяли відновити щонайменше захисну чутливість у дистальних відділах ушкодженої кінцівки. Хронічна електростимуляція структур периферійної нервової системи виявилась ефективним допоміжним методом впливу на процеси регенерації ушкоджених нервів верхньої кінцівки за умови їх критичної (в функціональному аспекті) ішемії.

Проведення корегуючого ортопедичного втручання, направленого на заміщення функції м'язів підвищення першого пальця у віддалені терміни, дозволило покращити власне оцінювання функції верхньої кінцівки у двох пацієнтів: із 60,4 до 64,6 балів у одного хворого - функція кінцівки так і залишилась задовільною, та у іншого із 56,3 до 70,8 балів - функція кінцівки із незадовільної стала доброю (рис. 2).

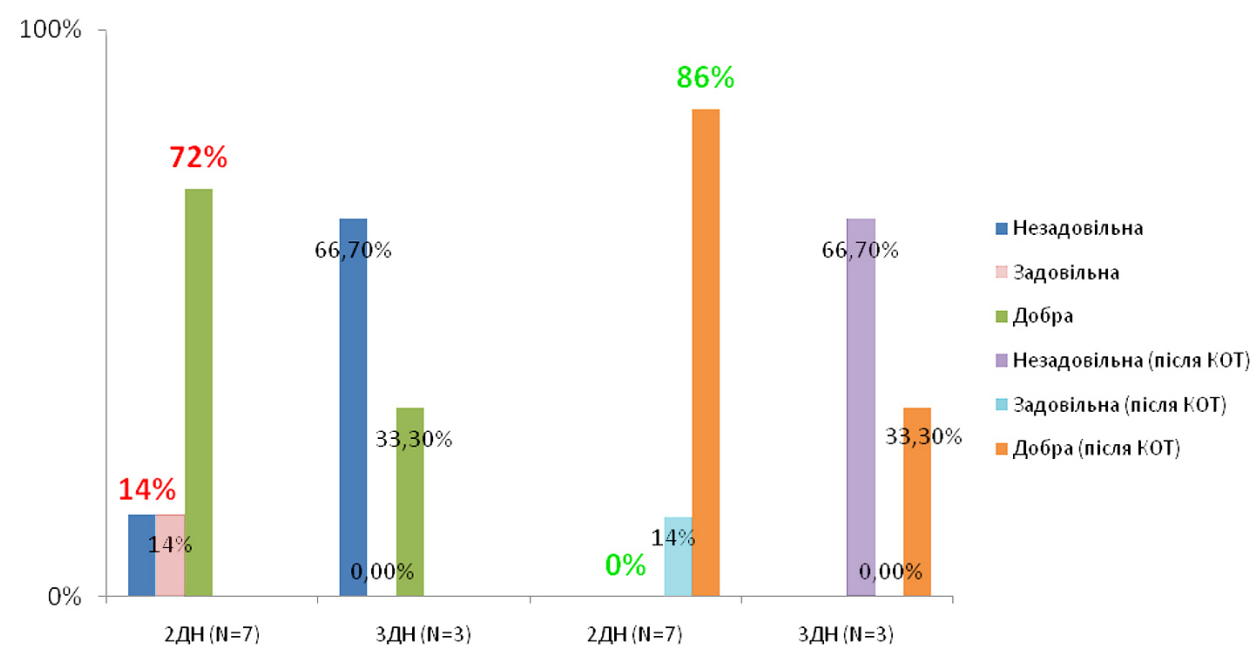

Рис. 2. Динаміка змін власного оцінювання функції ушкодженої верхньої кінцівки до та після проведеної ортопедичної корекції втрачених функцій: 2 ДН - вторинні ушкодження серединного та ліктьового нервів/м’язів ПФП; 3 ДН - вторинні ушкодження серединного, ліктьового та променевого нервів/м’язів ПФП та ЗФП.

Висновки. Застосування методики довготривалої електростимуляції нервів передпліччя за допомогою електростимуляційної системи Ней-Сі 3М, невролізу серединного та ліктьового нервів на передпліччі, ангіолізу плечової, променевої та ліктьової артерій, міолізу, є важливим інструментом у хірургічному лікуванні ушкоджень периферійних нервів, поєднаних із наслідками ішемічних розладів у м'язах передпліччя за типом контрактури Фолькмана. 
До факторів, що мали найбільший вплив на функціональне відновлення м'язового апарату переднього та заднього футлярів передпліччя, м’язового апарату кисті та чутливості в автономній зоні іннервації ушкоджених нервів, належать термін піс- ля травми та вік хворих. У пацієнтів із середнім терміном від травми до проведення реконструктивного втручання до п’яти місяців у віці до семи років проведені реконструктивні втручання дозволили повністю відновити функцію ушкодженої кінцівки.

\section{СПИСОК ЛІТЕРАТУРИ}

1. Концепція відновлення функції кінцівки при травматичному ушкодженні периферичних нервів / В. І. Цимбалюк, С. С. Страфун, О. Г. Гайко [та ін.] // Український нейрохірургічний журнал. - 2016. - № 3. - С. 48-54.

2. Sharma P. Results of the Max Page muscle sliding operation for the treatment of Volkmann's contracture of the forearm / P. Sharma, M. K. S. Swamy // J. Orthop. Traumatol. - 2012. Vol. 13. - P. 189-196.

3. Nerve injuries of the upper extremity associated with vascular trauma-surgical treatment and outcome / L. Rasulic, I. Cinara, M. Samardzic [et al.] // Neurosurg Rev. - 2017. - Vol. 40 (2). - P. 241-249.

4. Volkmann R. Die ischaemischen muskellahmungen und kontracturen / R. Volkmann // Zentralbl. Chir. - 1881. - Vol. 8. - P. 801-803.

5. Mubarac S. J. Compartment Syndromes and Volkmann's Contracture / S. J. Mubarac, A. R. Hargens. - Philadelphia : W. B. Saunders, 1981. $-232 \mathrm{p}$.

6. Grant C. Pediatric brachial artery injury due to supraco ndylar humerus fractures: A case series / C. Grant, M. Theiss, D. Mukherjee // Vascular. - 2019. - Vol. 27, (4). - P. 451-453.

7. Овсянкин Н. А. Оперативное лечение детей в поздней стадии ишемической контрактуры верхней конечности / Н. А. Овсянкин // Ортопедическое лечение детей с неврологическими заболеваниями. - М. : Б.и., 1986. - С. 81-84.

8. Сонографічне дослідження м'язів у хворих з наслідками травми периферичних нервів / О. Г. Гайко, С. С. Страфун, В.В.Гайович, Г. Я. Вовченко // Вісн. ортопедії, травматології та протезування. - 2013. - № 1. - С. 42-47.

9. Seddon H. J. Volkmann's contracture: treatment by excision

of the infarct / H. J. Seddon // J. Bone. Joint. Surg. - 1956. Vol. 32B. - P. 152-174.

10. Tsuge K. Management of established Volkmann's contracture / K. Tsuge // J. Bone Joint Surg. - 1975. - Vol. 57A. - P. 925-929. 11. Rubin G. Free myocutaneous flap transfer to treat congenita l Volkmann's contracture of the forearm / G. Rubin, B. Yaffe // J. Hand Surg. Eur. - 2015. - Vol. 40 (6). - P. 614-619.

12. Sollerman C. Sollerman hand function test. A standardized method and its use in tetraplegic patients / C. Sollerman, A. Ejeskar // Scand. J. Plast. Reconstr. Surg. Hand Surg. - $1995-$ Vol. 29. - P. 167-176.

13. Лелюк В. Г. Ультразвуковая ангиология / В. Г. Лелюк, С. Э. Лелюк. - М. : - 3-изд. Реал-Тайм, 2007. - 416 с.

14. Куликов В. П. Основы ультразвукового исследования сосудов / В. П. Куликов. - М. : Видар-М, 2015. - 392 с.

15. Страфун С. С. Клініко-електроміографічні та сонографічні критерії у визначенні тактики лікування хворих з ушкодженнями периферичних нервів внаслідок травми кінцівок / С. С. Страфун, О. Г. Гайко, I. М. Курінний // Травма. - 2013. - Т. 14, № 4. - С. 75-79.

16. Цимбалюк В. І. Хірургічне лікування ушкодження плечового сплетення з використанням довготривалої електростимуляції / В. І. Цимбалюк, І. Б. Третяк, Ю. В. Цимбалюк // Клініч. хірургія. - 2013. - № 6. - С. 59-61.

17. Чеботарьова Л. Л. Комплексна діагностика травматичних уражень плечового сплетення і периферичних нервів та контроль відновлення їх функції: автореф. дис. на здобуття наук. ступеня доктора мед. наук : спец. 14.01.05 “Нейрохірургія”, 14.01.15 “Неврологія” / Л. Л. Чеботарьова; Ін-т нейрохірургії ім. акад. А. П. Ромоданова АМН України. - К., 1998. - 31 с.

\section{REFERENCES}

1. Tsymbaliuk, V.I., Strafun, S.S., \& Haiko, O.H. (2016). Kontseptsiia vidnovlennia funktsii kintsivky pry travmatychnomu ushkodzhenni peryferychnykh nerviv [The concept of recovery of limb function in traumatic injury of peripheral nerves]. Ukrainskyi neirokhirurhichnyi zhurnal - Ukrainian Neurosurgical Journal, 3, 48-54 [in Ukrainian].

2. Sharma, P., \& Swamy, M.K.S. (2012). Results of the Max Page muscle sliding operation for the treatment of Volkmann's contracture of the forearm. J. Orthop. Traumatol., 13, 189-196. 3. Rasulic, L., Cinara, I., \& Samardzic, M. (2017). Nerve injuries of the upper extremity associated with vascular trauma-surgical treatment and outcome. Neurosurg. Rev., 40 (2), 241-249.

4. Volkmann, R. (1881). Die ischaemischen muskellahmungen und kontracturen. Zentralbl. Chir., 8, 801-803.

5. Mubarac, S.J., \& Hargens, A.R. (1981). Compartment syndromes and Volkmann's contracture. Philadelphia: W. B. Saunders.

6. Grant, C., Theiss, M., \& Mukherjee, D. (2019). Pediatric brachial artery injury due to supracondylar humerus fractures: A case series. Vascular, 27 (4), 451-453.

7. Ovsyankin, N.A. (1986). Operativnoe lecheniye detey v pozdney stadii ishemicheskoy kontraktury verkhney konechnos-

ti [Surgical treatment of children in the late stage of ischemic contracture of the upper limb]. Ortopedicheskoye lecheniye detey s nevrologicheskimi zabolevaniyami - Orthopedic Treatment of Children with Neurological Diseases. Moscow: B.i. [in Russian].

8. Haiko, O.H., Strafun, S.S., Haiovych, V.V., \& Vovchenko, H.Ya. (2013). Sonohrafichne doslidzhennia miaziv u khvorykh z naslidkamy travmy peryferychnykh nerviv [Sonographic examination of muscles in patients with peripheral nerve injury]. Visn. Ortopedii, travmatolohii ta protezuvannia - Bulletin of Orthopedics, Traumatology and Prosthetics, 1, 42-47 [in Ukrainian].

9. Seddon, H.J. (1956). Volkmann's contracture: treatment by excision of the infarct. J. Bone. Joint. Surg., 32B, 152-174.

10. Tsuge, K. (1975). Management of established Volkmann's contracture. J. Bone Joint Surg., 57A, 925-929.

11. Rubin, G., \& Yaffe, B. (2015). Free myocutaneous flap transfer to treat congenital Volkmann's contracture of the forearm. $J$. Hand Surg. Eur., 40 (6), 614-619.

12. Sollerman, C., \& Ejeskar, A. (1995). Sollerman hand function test. A standardized method and its use in tetraplegic patients. Scand. J. Plast. Reconstr. Surg. Hand Surg. 29, 167-176. 
13. Leliuk, V.H., \& Leliuk, S.E. (2007). Ultrazvukovaya angiologiya [Ultrasound angiology]. Moscow: Real-Taym [in Russian]. 14. Kulikov, V.P. (2015). Osnovy ultrazvukovogo issledovaniya sosudov [Basics of ultrasound examination of blood vessels]. Moscow: Vidar-M [in Russian].

15. Strafun, S.S. Haiko, O.H., \& Kurinnyi, I.M. (2013). Klinikoelektromiohrafichni ta sonohrafichni kryterii u vyznachenni taktyky likuvannia khvorykh z ushkodzhenniamy peryferychnykh nerviv vnaslidok travmy kintsivok [Clinico-electromyographic and sonographic criteria in determining the tactics of treatment of patients with peripheral nerve damage due to limb injury]. Travma - Trauma, 14 (4), 75-79 [in Ukrainian].

Електронна адреса для листування: kovalenkoiv@ukr.net
16. Tsymbaliuk, V.I., Tretiak, I.B., \& Tsymbaliuk, Yu.V. (2013). Khirurhichne likuvannia ushkodzennia plechovoho spletennia z vykorystanniam dovhotryvaloi elektrostymuliatsii [Surgical treatment of shoulder plexus damage using long-term electrical stimulation]. Klinich. khirur. - Clinical Surgery, 6, 59-61.

17. Chebotariova, L.L. (1998). Kompleksna diahnostyka travmatychnykh urazhen plechovoho spletennia i peryferychnykh nerviv ta kontrol vidnovlennia yikh funktsii [Comprehensive diagnosis of traumatic lesions of the brachial plexus and peripheral nerves and control of the recovery of their function]. Extended abstract of Doctor's thesis. A.P. Romodanov Institute of Neurosurgery of the AMS of Ukraine. Kyiv [in Ukrainian].

Отримано 22.10.2019

O.O. GATSKY ${ }^{1}$, A. I. TRETIAKOVA ${ }^{2}$, I. V. KOVALENKO르, I. B. TRETYAK ${ }^{1}$

A. Romodanov Institute of Neurosurgery, NAMS of Ukraine, Kyiv ${ }^{1}$

A. Herbachevskyi Regional Clinical Hospital, Zhytomyr ${ }^{2}$

\section{ISCHEMIC INJURIES TO THE ANTEBRACHIAL MUSCLES: AN ASSOCIATION BETWEEN CHRONIC INVASIVE ELECTRICAL STIMULATION OF THE NERVES AND FUNCTIONAL OUTCOME}

The aim of the work: to improve the effectiveness of the treatment of patients with nerve damage combined with forearm muscle ischemia through the use of reconstructive surgery techniques and long-term nerve stimulation.

Materials and Methods. The analysis of surgical treatment of ten patients with nerve injury, combined with supracondylar fractures of the humerus, complicated by ischemia of the muscles of the forearm. Representatives of the male sex accounted for $80 \%$ of the surveyed, female - $20 \%$. The average period from the moment of injury to reconstruction was 4.7 months. In all cases, surgical treatment was carried out - neurolysis, autoplasty, nerve suturing, angiolysis, removal of degeneratively altered tissues within the highest density of fascial-bone gaps. In 8 cases, reconstructive neurosurgical intervention was completed by implantation of a system for long-term direct stimulation of the NE-Si 3M nerves (VEL, Ukraine).

Results and Discussion. The proposed method led to a significant improvement in treatment outcomes in 80 \% of victims. Considering the complex mechanism of development of changes of the muscular apparatus due to the denervation and ischemic genesis, the elimination of at least the denervation effects, by stimulating the regenerative potential of the damaged peripheral nerve is a rather promising direction.

Key words: injury; nerves, Volkmann contracture; reconstructive surgery; microsurgery; electrical stimulation.

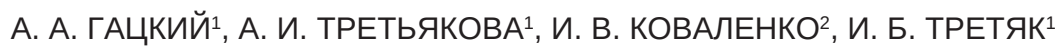

ГУ “Институт нейрохирургии имени академика А. П. Ромоданова НАМН Украины”, Киев Областная клиническая больница имени А. Ф. Гербачевского으, Житомир

\section{ОПЫТ ИСПОЛЬЗОВАНИЯ ДЛИТЕЛЬНОЙ ЭЛЕКТРОСТИМУЛЯЦИИ ПРИ ПОВРЕЖДЕНИЯХ НЕРВОВ, СОЧЕТАННЫХ С ИНЕМИЕЙ МЫНШЦ ПРЕДПЛЕЧЬЯ}

\footnotetext{
Цель работы: повысить эффективность лечения больных с повреждениями нервов, соединенных с ишемией мышц предплечья путем использования методик реконструктивной хирургии и длительной электростимуляции нервов.

Материалы и методы. Проведен анализ хирургического лечения десяти больных с травмой нервов, соединенных с супракондилярнимы переломы плечевой кости, осложненных ишемией мышц предплечья. Представители мужского пола составляли 80 \% обследованных, женского - 20 \%. Средний срок с момента получения травмы до проведения реконструктивного вмешательства составил 4,7 месяцев. Во всех случаях проведено хирургическое лечение - невролиз, аутопластика, сшивания нервов, ангиолиз, удаление дегенеративно измененных тканей в пределах наибольшей плотности фасциально-костных промежутков. В 8 случаях реконструктивное нейрохирургическое вмешательство завершалось имплантацией системы для долговременной прямой электростимуляции нервов “Ней-Си ЗМ” (ВЭЛ, Украина).

Результаты исследований и их обсуждение. Предложенная методика позволила достичь существенного улучшения результатов лечения у 80 \% пострадавших. Учитывая сложный механизм развития изменений мышечного аппарата вследствие денервационных и ишемического генеза, устранение минимум денервационных эффектов путем стимуляции регенерационного потенциала поврежденного периферического нерва является довольно перспективным направлением.
}

Ключевые слова: травма нервов; контрактура Фолькмана; реконструктивная хирургия; микрохирургия; электростимуляция. 